\title{
Cold Seeps and Associated Communities of the Gulf of Mexico
}

BY CHARLES FISHER, HARRY ROBERTS, ERIK CORDES, AND BERNIE BERNARD

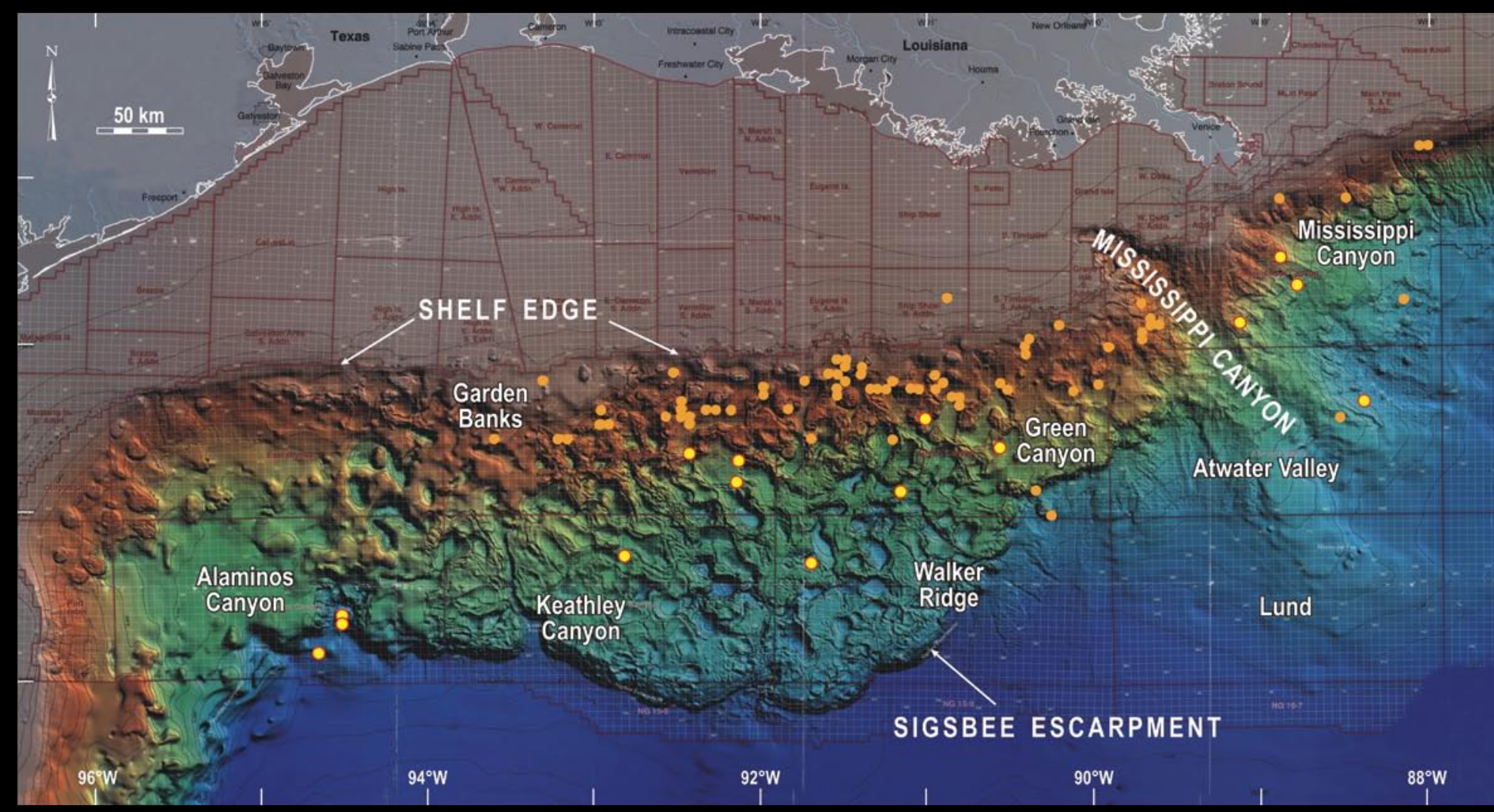

Figure 1. Multibeam bathymetric image of the northern Gulf of Mexico showing the location of all seep sites where seep-animal communities have been confirmed by ROV or manned submersible dives. Sites visited during the 2006 and 2007 Deep Slope cruises jointly supported by the Minerals Management Service and the NOAA Ocean Exploration Program are indicated by yellow circles outlined in red. 
Cold-seep communities associated with brine and hydrocarbon seepage on the upper Louisiana slope (ULS) of the Gulf of Mexico (GoM) were among the first discovered (Kennicutt et al., 1985), and they have become the most intensively studied and best understood of any coldseep communities in the world. This recognition results from several factors: (1) There is a diverse funding base for this work, including the US Department of Interior Minerals Management Service, the National Oceanic and Atmospheric Administration (NOAA) National Undersea Research Program, the NOAA Ocean Exploration Program, and the US National Science Foundation, as well as a high level of interagency cooperation among these programs and with industry (see Kendall et al., this issue). (2) The relatively simple logistics of working at these intermediatedepth (320-800-m depth) sites, which are within 12 hours transit of a variety of US ports, has allowed near annual submersible visits to some of them for almost two decades of detailed, process-oriented studies. (3) Many of the animals from these seeps can be maintained alive in the laboratory at ambient pressure, and a variety of experiments with living animals has lead to a relatively detailed understanding of their physiology. (4) Oil, gas, and brine seepage is extremely widespread over a large portion of the GoM; over 90 sites from the base of the Florida Escarpment at $84^{\circ} 55^{\prime}$ in the east to $94^{\circ} 49^{\prime}$ in the west, and from 290-m to 3300-m depth have been confirmed by remotely operated vehicle (ROV) or manned submersible to harbor chemosynthetic macrofau- nal communities (Figure 1). These factors have allowed a variety of research groups to develop and test the generality of hypotheses stemming from intensive study of a few sites, and to unravel the relative roles of depth, substrate characteristics, fluid expulsion dynamics, chemistry, and biogeography in structuring seep communities.

The widespread occurrence of seep communities in the GoM is a direct result of its geologic history. Understanding the dynamics and biogeography of the communities is impossible without understanding the complex geology and geochemistry of the modern Gulf. Our initial discovery of hydrocarbonseep communities (Kennicutt et al., 1985) was a direct result of Minerals Management Service oversight of oil and gas exploration and production activities. Discovery of new sites and communities continues to be largely derived from oil and gas exploration activities and industry-generated coring, multibeam bathymetric mapping, and three-dimensional seismic surveys. In this review, we begin with an overview of GoM geologic history and our current understanding of the geological forces that produce the surface expression of seepage and support the seep communities. We summarize current knowledge about seepage extent in the GoM, the confirmed distribution of macrofaunal seep communities, and the likely geographic extent of these communities. We then review what we have learned during two decades of studying these remarkable animals and communities, and discuss our continued exploration and discovery of new sites, animals, and communities.

\section{GEOLOGY OF THE} CONTINENTAL SLOPE OF THE GULF OF MEXICO

Since the late Cretaceous when uplift of the Rocky Mountains began, massive volumes of sediment have been delivered to the northern Gulf of Mexico. The early pulses of sediment were deposited over thick Jurassic salt beds formed during the early stages of GoM evolution. The interaction between sediment loading and compensating deformation of underlying salt has continued through the Quaternary. As a result, the continental slope of the northern GoM is one of the most geologically complex deepwater settings in today's ocean. Because the Gulf is a prolific hydrocarbon-producing basin, the dynamic geologic framework created by sediment deposition and salt deformation provides many "leak points" for subsurface fluids and gases to reach the modern seafloor.

In the 1990s, advances in seismic technology, the shift from analog to digital data acquisition, and the rapid evolution of computing power and software dramatically changed our view of the subsurface and its salt-sediment relationships. Prior to the mid 1980s, geologists and geophysicists generally believed that the northern Gulf of Mexico basin was dominated by deeply rooted salt stocks and massifs with associated growth faults. This concept has been replaced by a geologic framework that incorporates more horizontally mobile salt sheets and canopies (Diegel et al., 1995; McBride et al., 1998). Figure 2 is a cross section of the northern Gulf's shelf and continental slope showing sediment thicknesses and generalized salt geometries typical of the 


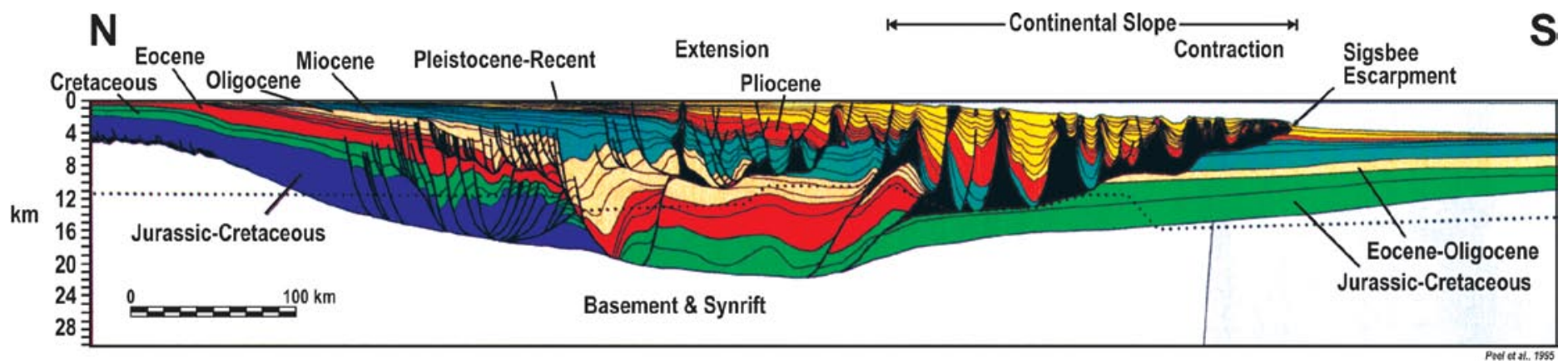

Figure 2. A north-south geologic cross section of the northern Gulf of Mexico basin illustrating the complex relationships between sediments and salt (black). The thick intraslope sedimentary basins, salt bodies, and numerous faults of the continental slope provide a geologic framework that favors "leakage" of subsurface fluids and gases to the modern seafloor. The cross section is an interpretation of two-dimensional seismic data ground truthed using drilling data. From Peel et al., 1995

area between onshore Louisiana and the deep Gulf floor (Peel et al., 1995). Improved imaging of salt bodies using three-dimensional seismic data has led to a new appreciation of the mobility of salt when forced by sediment loading (Rowan 1994; McBride 1998).

Historically, when it was realized that the Sigsbee Escarpment at the base of the northern Gulf's continental slope was a product of Jurassic salt being thrust over much younger sediments (DeJong, 1968), it triggered research leading to our present appreciation of salt's mobility and impact on the geologic complexity of the continental slope. Humphries (1978) observed that salt thrusting at the toe of the slope was a product of sedimentary loading on the upper slope. By the late 1980s, industry geoscientists, with the aid of three-dimensional seismic data, were clearly imaging salt sheets and canopies where salt stocks were interpreted from earlier-generation, twodimensional seismic profiles. A review of the Cenozoic evolution of the northern Gulf of Mexico basin by Worrall and Snelson (1989) emphasized the basinward movement of salt and growth fault- ing as sediments were deposited on the outer shelf and upper slope. By the early 1990s, researchers, primarily from the oil and gas industry, recognized the link among sediment, salt, and structural systems, and also that minibasins occurring on the continental slope were the results of mobile-salt evacuation (Sumner et al., 1990). Vendeville and Jackson (1993) showed that variations in the rate of sediment deposition affect the deformation of salt bodies, which in turn exerts strong control on the locations and orientations of minibasins and associated faults (Figure 1). Oil generation and migration are critically tied to overlying sediments and the time-dependent changes in the geometries of salt bodies. The impermeable nature of salt prevents vertical migration in given areas and deflects hydrocarbon migration laterally. Therefore, the edges of salt bodies and their associated faults commonly focus gas migration to the modern seafloor (Rowan et al., 1999).

The enormous database acquired from three-dimensional seismic surveys and coring operations conducted on the northern Gulf of Mexico continental slope provides a means of locating and estimating the number of hydrocarbonseep sites throughout the slope province. Migration pathways for fluid and gas to the modern seafloor are largely determined by the presence of salt in the subsurface, salt geometries, and associated faulting. Acoustic data sets (threedimensional seismic sections, multibeam bathymetric maps, and side-scan sonar images) often display intraslope basins as "smooth" or featureless areas surrounded by regions of elevated and bathymetrically "rough" seafloor (Figure 1). These complex areas that form the boundaries of the salt-withdrawal minibasins are

CHARLES FISHER (cfisher@psu.edu) is Professor of Biology, The Pennsylvania State University, University Park, PA, USA. HARRY ROBERTS is a Boyd Professor in the Department of Oceanography and Coastal Sciences, Louisiana State University, Baton Rouge, LA, USA. ERIK CORDES is Postdoctoral Fellow, Harvard University, Cambridge, MA, USA. BERNIE BERNARD is Vice President and Chief Technology Officer, TDI-Brooks International, Inc., College Station, TX, USA. 
generally salt-supported and faulted, and are sites of vertical fluid and gas migration to the modern seafloor. Starting in the mid 1980s, "ground-truth" surveys of venting and seeping areas on the upper continental slope using manned submersibles provided a clear correlation between surface amplitude or reflectance anomalies derived from three-dimensional seismic data and areas of seepage (Roberts et al., 2006). "Hard bottom" returns or areas of high amplitude generally are related to authigenic carbonates that are by-products of the hydrocarbon seepage process. These data sets confirm that seepage is primarily confined to the margins of intraslope basins where most chemosynthetic communities have been found (Roberts et al., 2006).

\section{SEAFLOOR RESPONSES TO THE}

\section{EXPULSION PROCESS}

When high-resolution seismic and sidescan sonar data became widely used by industry for geohazard assessments, pipeline surveys, and drilling-site evaluation, it became apparent that the slope seafloor was much more geologically complex than previously envisioned from low-frequency (low-resolution), exploration-scale seismic data. Even though abundant historical records of GoM oil slicks, tar on beaches, and bubbling gas were available (Geyer and Giammona, 1980), it was not until the early to mid 1980s that the abundance of seeps on the continental slope was realized. During this time, a variety of projects revealed oil-stained sediments, gas hydrates, authigenic carbonates, and chemosynthetic organisms at seepage sites on the ULS (e.g., Kennicutt et al., 1985; Brooks et al., 1986; Roberts et al., 1989). Beginning in 1986, GoM investigators using manned submersibles were finally able to begin to confidently "calibrate" coring and acoustic data acquired from surface ships with actual seafloor conditions, characteristics, and biological communities. As of 2007, over 90 different deep-seep sites have been visited by manned submersibles and ROVs in the northern GoM, and seep-animal communities have been confirmed at 84 sites (Figure 1). Others have been documented at the base of the Florida Escarpment (Paull et al., 1984) and in Mexican waters in the southern Gulf (MacDonald et al., 2004). The number of confirmed seep sites in the GoM rivals that of all other deep-seep sites visited in the world's ocean combined. Hundreds of other sites likely to harbor seep animal communities have been identified from coring activities in the GoM and from interpretations of three-dimensional seismic data. Figure 3 illustrates the locations of piston cores that unambiguously exhibit oil or gas in the top five meters of sediment. Additional sites with significant macrofaunal communities will no doubt be discovered as we continue to ground truth potential sites identified from analyses of piston cores and threedimensional seismic data.

The geological and biological impacts of fluid-gas expulsion processes on the seafloor are related to the composition of products being delivered to the seafloor, the rate of delivery of these products, and the history of seepage at a given site (Roberts and Carney, 1997). These products are primarily hydrocarbons (biogenic and thermogenic gas and crude oil) and brines, and occasionally fluidized sediment. Delivery rates range

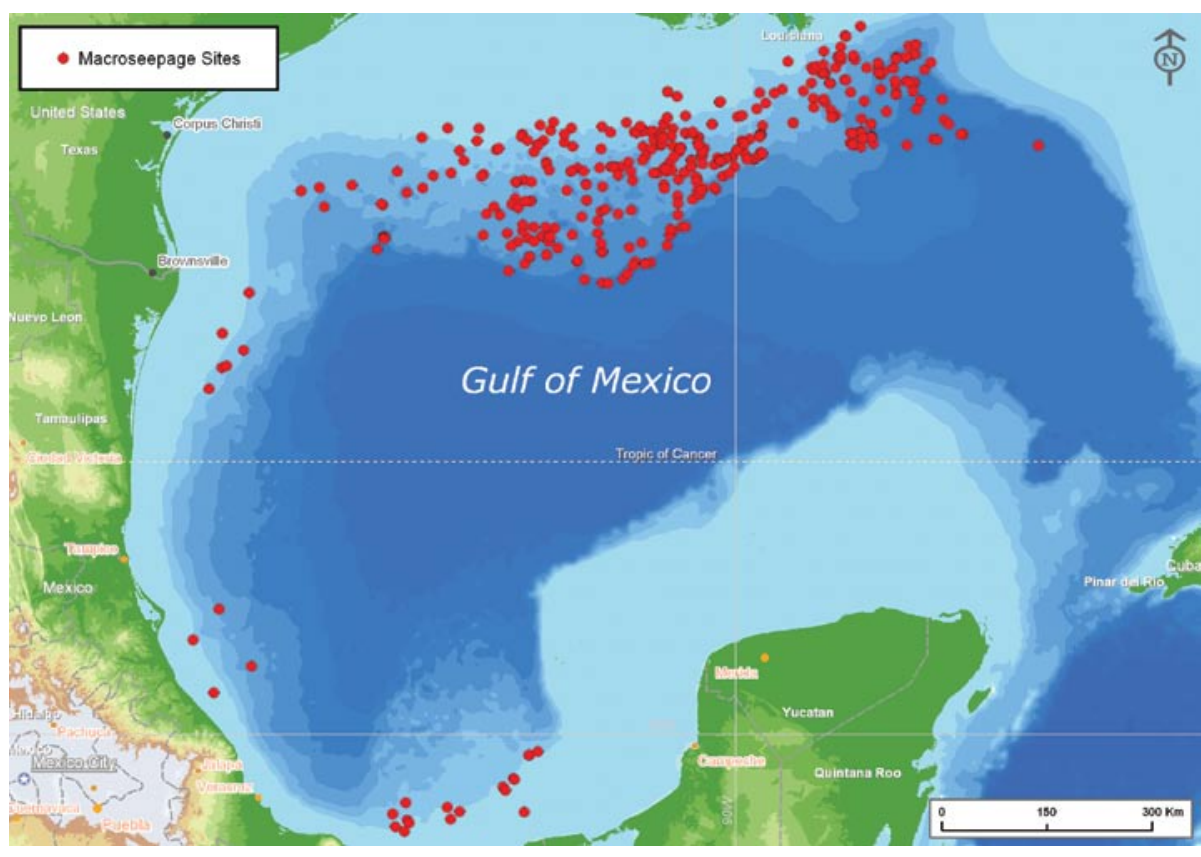

Figure 3. The red dots show Gulf of Mexico locations of industry-recovered piston cores that have significant levels of oil (greater than 300,000 Total Scanning Fluorescence maximum intensity units) or methane (greater than 100,000 ppm) present in the top five meters of sediment. Courtesy of TDI-Brooks International 
from slow "seepage" to rapid "venting." The biological and geological seafloor responses to variable end-member and intermediate hydrocarbon delivery rates range from fluidized sediment forming mud volcanoes and mud flows to seafloor cementation by carbonates as a byproduct of microbial metabolism of hydrocarbons (Figure 4). When delivery products and rates are compatible with a physically stable seafloor and provide the appropriate trophic resources for chemoautotrophy and methanotrophy, densely populated and diverse animal communities may arise. The composition of these communities can change as the nature of the seepage evolves.

\section{BIOLOGY OF SEEPS ON THE UPPER LOUISIANA SLOPE OF THE GULF OF MEXICO}

We discuss seeps on the ULS first because the large database derived from processoriented studies on these communities provides the background needed for understanding cold-seep communities at greater depths in the GoM and in other parts of the world. Microbial activity forms the primary connection between geological processes and the macrobiological communities. Although the methane at many of the GoM seep sites is predominately thermogenic, at other sites there is a significant contribution of microbially produced biogenic methane
(Sassen et al., 1994). Microbial mats are the first visually recognizable and most common biological response to seepage in the Gulf and are present to some extent at every seep site visited.

Megafauna are occasionally seen on microbial mats but most mats remain relatively free of visible grazers. Nonetheless, free-living bacteria (presumably growing on mussel shells and tubeworm tubes) form the foundation of the local food webs for the nonsymbiotic seep fauna, as they do at hydrothermal vents (MacAvoy et al., 2005). Microbial consortia activity that oxidizes methane and reduces sulfate is key to the macrofaunal communities.

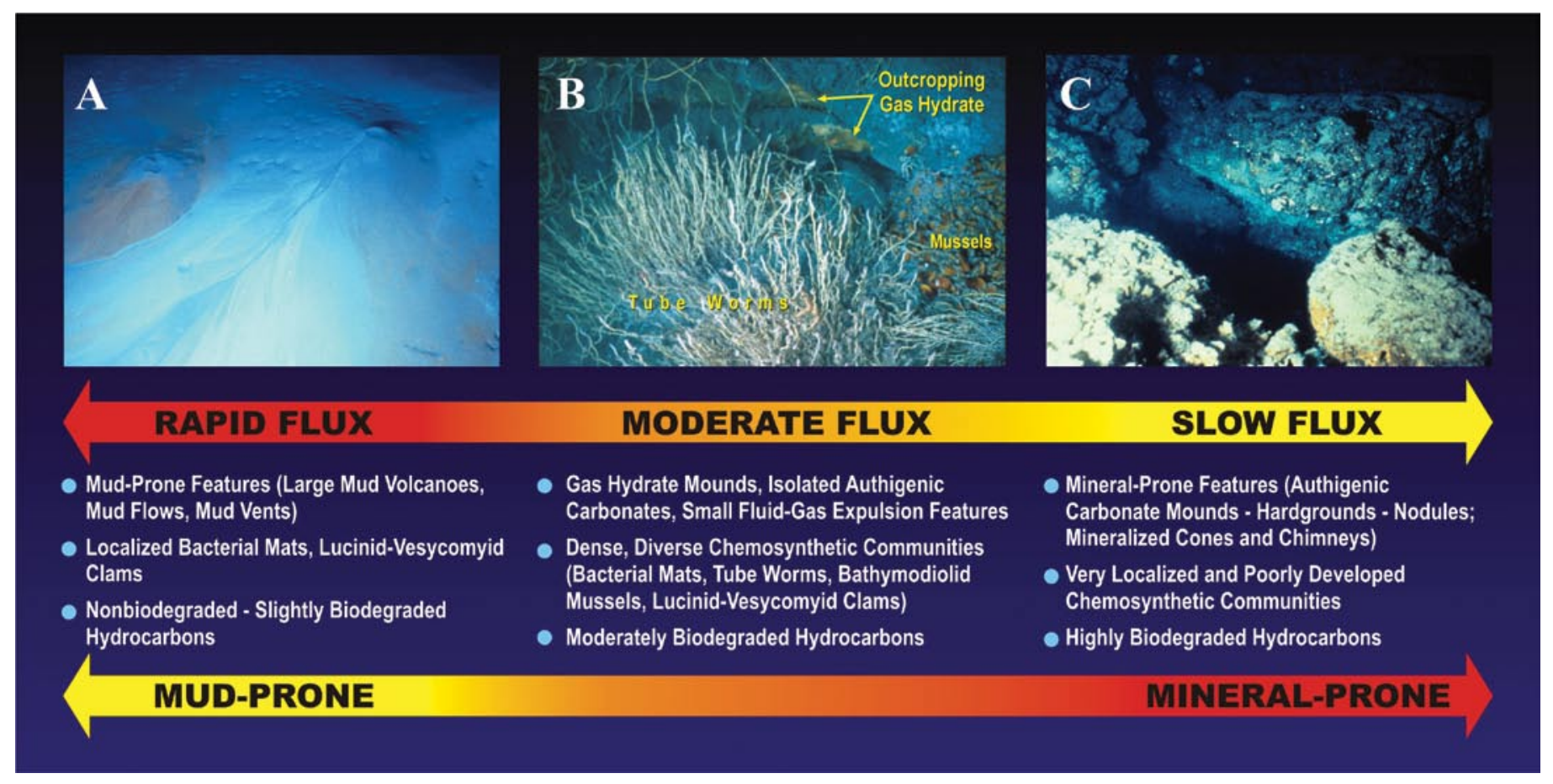

Figure 4. Qualitative relationships between rates of fluid-gas expulsion to the modern seafloor and geologic-biologic responses. (A) Rapid flux systems are mud-prone and tend to produce mud volcanoes, mud vents, and mudflows with very limited macrofaunal communities. (B) Moderate flux systems support well-developed macrofaunal communities and are commonly associated with surficial exposures of gas hydrate or gas hydrate in the shallow subsurface. (C) Slow flux systems are mineral-prone and produce authigenic carbonates in many forms. Release of reduced chemicals from the seafloor in slow-flux systems is generally quite low and cannot support macrofauna dependent upon high levels of epibenthic methanotrophy or chemoautotrophy. Through time, the fluxes of fluids and gases may vary, and systems often appear to have evolved from more rapid flux to slower flux over hundreds of years. Under these conditions, the associated communities also evolve. Modified from Roberts, 2001 
This activity contributes to carbonate precipitation, which stabilizes sediment and produces the hard substrate necessary for attachment and growth of tubeworms, corals, and other fauna, and also produces the sulfide required by tubeworms, some mussels, and free-living aerobic chemoautotrophs (Joye et al., 2004). Furthermore, symbiosis with chemoautotrophic and/or methanotrophic microbes led to the dominance of mussels and tubeworms at the GoM seeps as at many other seeps and vents around the world (Nelson and Fisher, 1995; Sibuet and Olu, 1998).

Symbiont-containing bathymodiolin mussels are one of the dominant foundation species at seep sites in the GoM. On the ULS, Bathymodiolus childressi, a mussel with methanotrophic symbionts (Childress et al., 1986) often forms extensive beds that support abundant communities of associated fauna. B. childressi collected from depths above about $1000 \mathrm{~m}$ can survive at ambient pressure; we have maintained individuals in aquaria for over five years, allowing extensive laboratory studies. B. childressi can grow with methane as its sole carbon and energy source (Cary et al., 1988), can use ammonia or nitrate as sources of nitrogen (Lee et al., 1992), and can supplement its nutrition with filter feeding (Page et al., 1990). B. childressi does not have any blood pigments to bind or accumulate methane, but requires the presence of free methane dissolved in seawater in substantial micromolar concentrations to survive (Kochevar et al., 1992; Nix et al., 1995). Therefore, the presence of a living community of B. childressi on the seafloor is an indicator of active and ongoing fluid or gas expulsion, and mussel beds are often associated

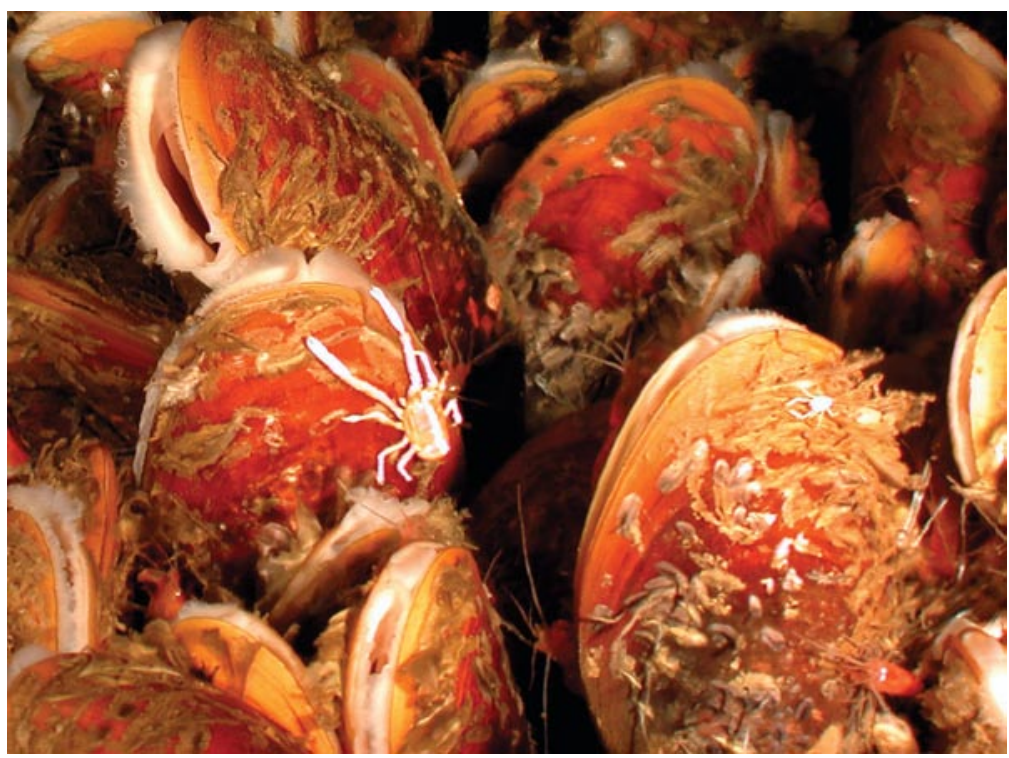

Figure 5. Close-up image of a bed of the mussel Bathymodiolus childressi in Green Canyon lease block 233 at 630-m depth on the upper Louisiana slope of the Gulf of Mexico. The shrimp Alvinocaris stactophila and crabs Munidopsis spp. are common seependemic fauna on the upper Louisiana slope.

with visible bubble streams of methane.

Unlike bacterial mats, mussel beds offer a three-dimensional habitat structure with surfaces on which to graze and interstices that provide refuge from predators. A high-biomass but low-diversity community, dominated by seep-endemic macro- and megafauna that can tolerate exposure to seep fluids, characterizes these productive mussel beds (Bergquist et al., 2005). Although some small predatory macrofauna species are present, primary consumers, particularly depositfeeding polychaetes and grazing gastropods and decapods, dominate the mussel bed communities on the ULS (Figure 5, Bergquist et al., 2005).

Two species of vestimentiferan tubeworms (siboglinid polychaetes), Lamellibrachia lumeysi and Seepiophila jonesi, are abundant on the ULS, and both have been maintained in the laboratory for study at ambient pressure for many years. Another rare and undescribed species of escarpid tubeworm is occasionally collected on the ULS but is poorly studied. Like all known vestimentiferans, these tubeworms have no mouth, gut, or anus and rely on their intracellular symbionts for the bulk of their nutrition (Nelson and Fisher, 1995). Their symbionts use sulfide as an energy source, and the tubeworms have specialized hemoglobins in their blood and coelomic fluid that not only bind and transport oxygen, but also sulfide. These sulfide-binding pigments allow them to acquire sulfide from relatively low environmental levels and also to transport sulfide from the environment to symbionts housed in their internal organs (Fisher et al., 1988). Unlike the well-studied vent species from the East Pacific Rise, GoM seep tubeworms grow long posterior extensions that appear to function in ways similar to the roots of 
a plant (Julian et al., 1999). These tubeworm "roots" can extend meters into the sediment and can be used to take up sulfide from interstitial sources, thus decoupling their persistence from the release of sulfide above the sediment-water interface (Freytag et al., 2001). Furthermore, L. luymesi releases a portion of the sulfate produced from the oxidation of sulfide back across its roots into the sediment (Dattagupta et al. 2006), which can act as an electron acceptor for microbial consortia using methane and hydrocarbons as an energy source and thereby replenish the local supply of sulfide around their roots (Cordes et al., 2005a). These adaptations allow individual L. luymesi and S. jonesi, and aggregations of the two species, to live for centuries (Bergquist et al., 2000; Cordes et al., 2007a), and also help to drive the succession of animal communities associated with the tubeworms described below.

Tubeworm aggregations require a sufficiently stabilized substrate for attachment, which in the GoM is normally provided by authigenic carbonates produced as a byproduct of microbial alteration of seeping hydrocarbons.

Survival of planktonic larval tubeworms to the juvenile stage requires their arrival at a seafloor environment where tiny, newly metamorphosed juveniles will find co-occurring sulfide and oxygen over an appropriate settlement substrate to fuel their chemoautotrophic lifestyle. Larval tubeworm settlement persists for 20-60 years for most aggregations on the ULS (Bergquist et al., 2002). During this time, the small but complex biogenic structures created by young tubeworms tend to be bathed in reduced chemicals

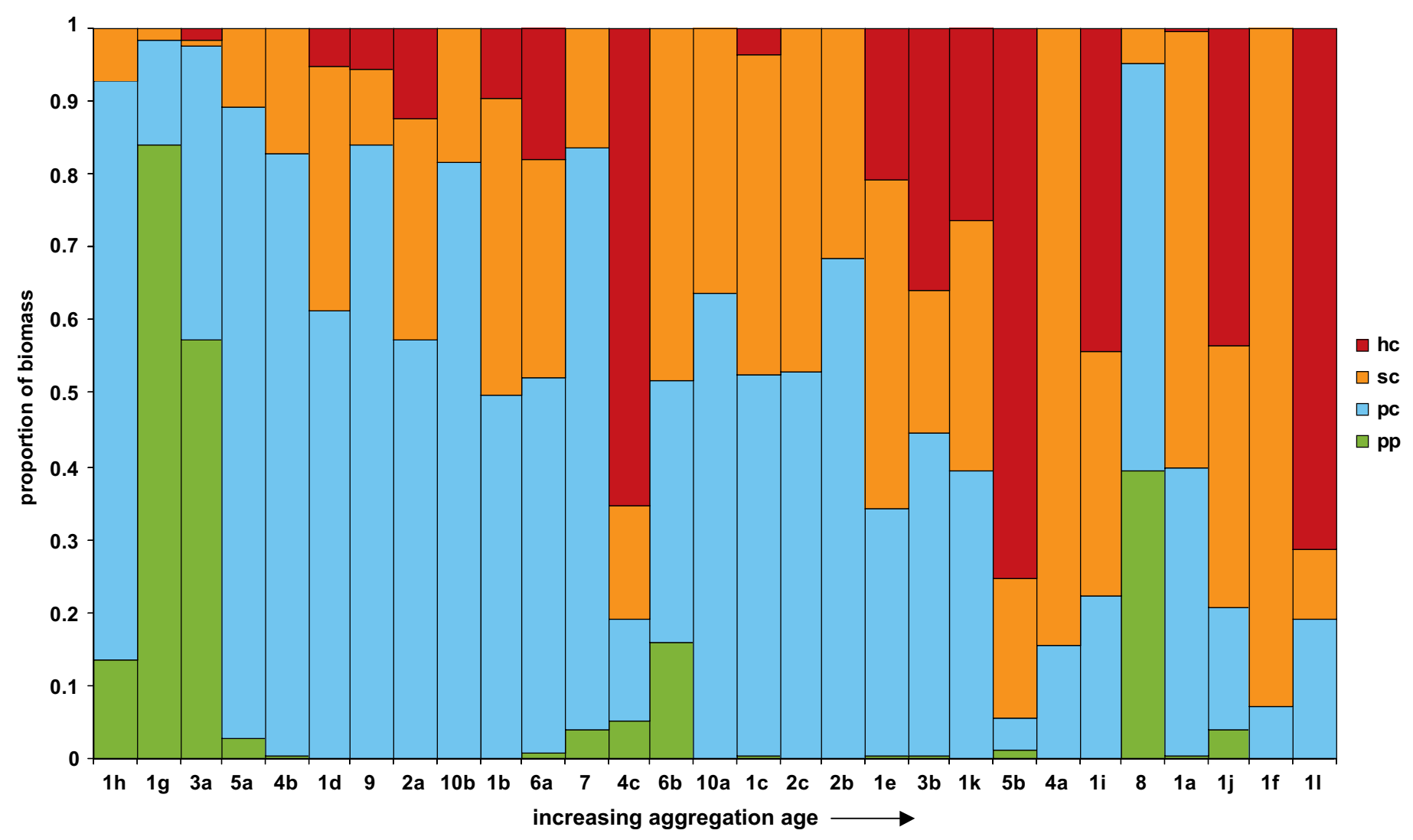

Figure 6. Trophic structure of tubeworm-associated communities on the upper Louisiana slope of the Gulf of Mexico. Each bar represents a single quantitative community collection ordered from youngest to oldest (aggregation age is approximated by the average length of the tubeworms in each aggregation). The proportion of biomass (ash-free dry weight) in each trophic level is shown. Primary producers (pp in green) are bivalves with chemoautotrophic or methanotrophic symbionts (this category does not include the tubeworms, which produce the structure for the communities and represent over $95 \%$ of the biomass in each aggregation). Primary consumers (pc in blue) include grazing and deposit-, filter- and suspension-feeding species. Secondary consumers (sc in yellow) include predatory worms, snails, and small crabs. Higher-order consumers (hc in red) include fishes, sea stars, and large crustaceans. Sites are labeled as in Cordes et al., 2006: 1 - GC243, 2 - GC232, 3 - GC185, 4 - GC233, 5 - GC354, 6 - GB543, 7 - GB544, 8 - GB535, 9 - MC885, 10 - VK825. 
(Bergquist et al., 2003; Cordes et al., 2006), facilitating free-living bacterial production but also producing a habitat toxic to many other species. During this tubeworm settlement and early growth period, communities associated with young tubeworm aggregations are dominated by seep-endemic primary consumers also found in B. childressi mussel beds (Bergquist et al., 2003; Cordes et al., 2005b; Figure 6).

Tubeworm settlement ultimately ceases when no additional hard substrate exposed to sufficient sulfide above the seafloor is available to support the newly metamorphosed juveniles, which lack long posterior extensions capable of mining sulfide (Bergquist et al., 2002). Following this initial settlement period, there is a post-settlement phase where tubeworm individuals, and therefore aggregations, increase in size and where release of reduced chemicals from the sediment decreases dramatically while tubeworms increase their reliance on their roots to obtain sulfide. During this time, the amount of habitat produced by the tubeworm tubes can be quite large (single aggregations are often more than a meter in height and several meters in diameter; Figure 7), and some reduced chemicals may still be present within the aggregation near the seafloor but are absent from portions further from the seafloor (Freytag et al., 2001). Diversity of associated fauna during these intermediate stages can be quite high (up to 47 species in a single aggregation), and the food-web complex includes many nonendemic and predatory species not typically seen in earlier successional stages (Bergquist et al., 2003; Cordes et al., 2005b). As the aggregations continue to age, sulfide expression above the

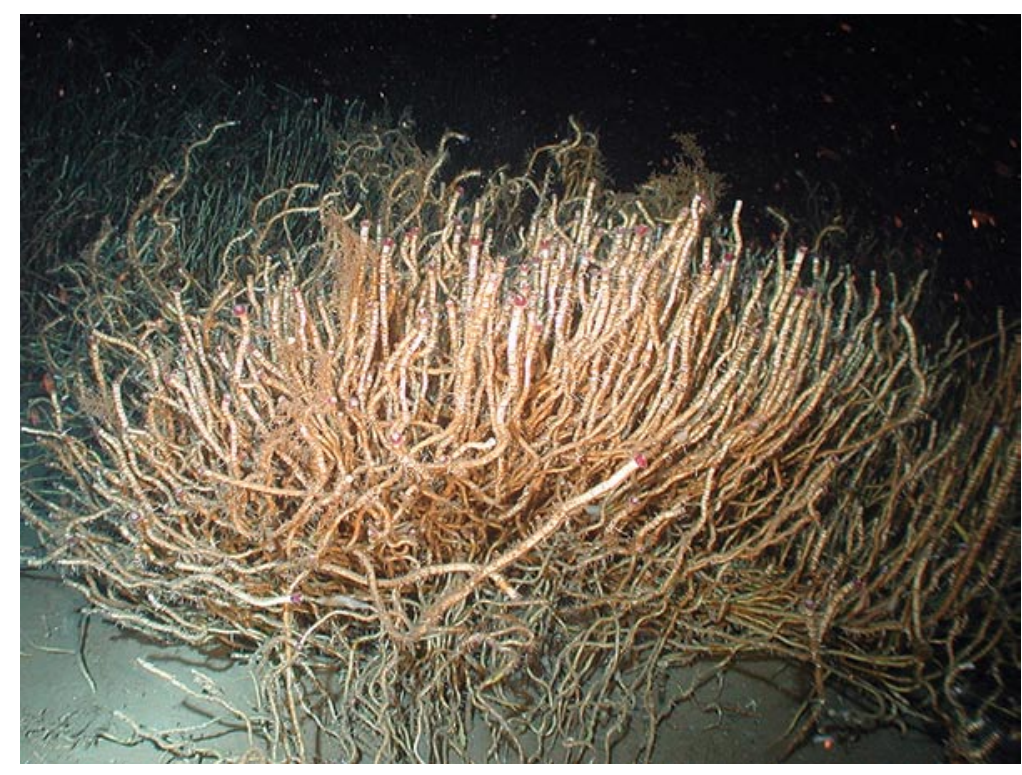

Figure 7. Aggregation of tubeworms (siboglinid polychaetes) in the Green Canyon lease block 234 at 540-m depth on the ULS. Lamellibrachia luymesi is the visually dominant tubeworm in these aggregations as it normally grows with its plume and anterior end a meter or more above the sediment, while Seepiophila jonesi normally maintains its plume very close to the sediment-water interface. Photo courtesy of E. Cordes

sediment surface largely ceases and the diversity of the associated fauna begins to drop off. The relative proportion of endemic animals (proportion of species and biomass) steadily declines (to $<50 \%$ in the oldest aggregations), and there is an increase in the abundance of animals in higher trophic levels (Figure 6; Cordes et al., 2006). The abundance of nonendemic predators in these seep environments contrasts sharply with the very high rates of endemicity in vent environments ( 95\%; Tunnicliffe, 1991). These relationships suggest that while predation plays a relatively minor role in the assembly of the ephemeral vent communities (Micheli et al., 2002), it may substantially influence the structure of the longer-lived seep communities.

Finally, perhaps as a result of carbonate precipitation, resource depletion in the sediments, and/or very old age, tubeworm aggregations begin to senesce and thin out as a result of mortality. The diversity, proportion of endemics, and overall biomass of associated fauna are low, but sessile fauna heavily colonize the tubes (Bergquist et al., 2003; Cordes et al., 2006). These aggregations sometimes appear as clusters of recumbent individuals in heavily sedimented areas (with up to a meter of the tube above the point of initial attachment buried) or as the tops of sparse aggregations protruding from the surface of carbonate outcrops. Authigenic carbonates produced during periods of more active seepage persist and are often further exposed by erosion of surrounding soft sediments. In some areas, exposed carbonates are colonized by hard and soft corals that co-occur with old tubeworm aggregations (Figure 8). In other areas, seep fauna reliant upon methanotrophy or chemoautotrophy are 


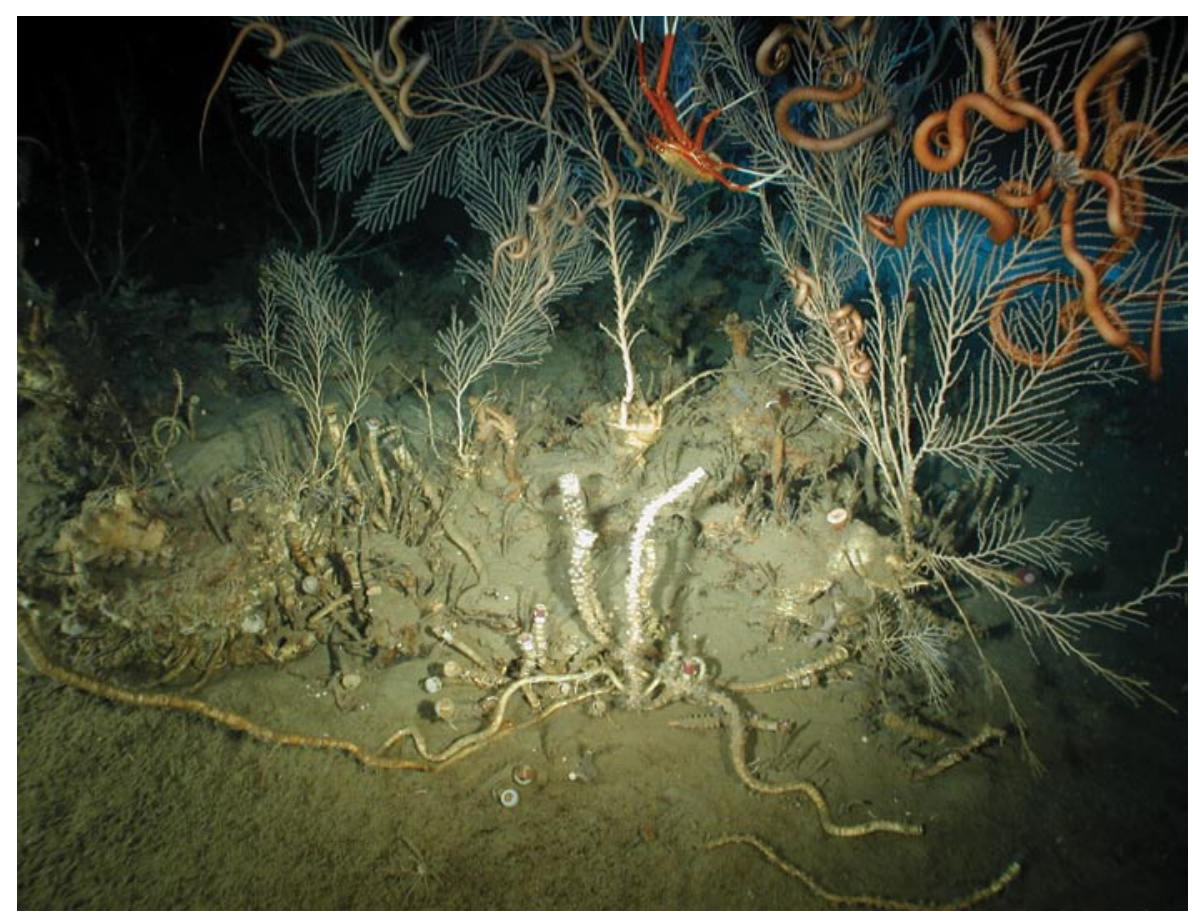

Figure 8. Tubeworms (Lamellibrachia luymesi and Seepiophila jonesi), corals (predominantly Callogorgia americana delta), and associated fauna on authigenic carbonate in Green Canyon lease block 234 at 540-m depth. Photo courtesy of D. Bergquist

sparse or entirely lacking, and carbonates may be densely covered with corals. The fauna closely associated with these corals include some of the same species found in older tubeworm aggregations; however, fauna endemic to mussel beds or young tubeworm aggregations are extremely rare among corals. Conversely, there are several common coral-associated species not found in association with tubeworms even when both are present within meters of each other (Cordes et al., in press). Direct trophic ties between deep-sea corals and seep primary production have never been demonstrated. However, the carbonates that form at seeps present the hard substrate necessary for coral colony formation in areas where the surrounding seafloor is soft sediment, and thus provide a direct link between cold seeps and coral communities in the deep Gulf of Mexico.

In addition to the well-studied tubeworm and mussel communities on the ULS, several other types of seep ani- mals are worthy of mention. Although dense, living communities of symbiontcontaining vesicomyid clams, which have been reported from other seep sites (Sibuet and Olu, 1998), have not been found in the GoM, C. ponderosa and $V$. chordata are often present in low densities on the ULS (Brooks et al., 1987). A rather unusual monospecific community of specialized polychaetes ("iceworms," Hesiocaeca methanicola) has also been found associated with exposed gas hydrates at several different sites on the ULS (Fisher et al., 2000: see Box 3 in Kendall et al., this issue).

\section{SEEP COMMUNITIES AT $>$ 1000-M DEPTH IN THE GULF OF MEXICO}

In 1984, Alvin dives on the base of the Florida Escarpment at about 3300-m depth revealed the first known coldseep ecosystems consisting of thriving communities of tubeworms and mussels associated with brine seepage
(Paull et al., 1984). Over the next two decades, only a handful of new seep sites were discovered at depths greater than $1000 \mathrm{~m}$ in the GoM (Brooks et al., 1990; MacDonald et al., 2003, 2004). During 2006 and 2007, the Department of Interior Minerals Management Service and the Department of Commerce NOAA Ocean Exploration Program jointly supported cruises (see Kendall et al., this issue) where ten new sites on the lower Louisiana slope in the GoM were discovered and characterized, and an additional five previously known (but largely unstudied) sites at greater than 1000-m depth were further explored (Figure 1, color-coded sites). These sites contained numerous high-density communities of tubeworms and mussels. Several discoveries were made during these expeditions, including a large community of deep-living soft and hard corals, the largest mussel bed known in the Gulf, an actively venting mud volcano, asphalt seeps at only $1250-\mathrm{m}$ depth, a spectacular brine lake, and a variety of new species. Results from these explorations are still being analyzed, although a report from the 2006 cruise has already been published (Roberts et al., 2007), and photos and preliminary data from both cruises are available on the Ocean Explorer Web site (http://www. oceanexplorer.noaa.gov).

At the sites below $1200 \mathrm{~m}$, the species of tubeworms present on the ULS are replaced with two undescribed species in the genera Lamellibrachia and Escarpia. The aspects of seep tubeworm physiological ecology and life history described above for the shallower-living species most likely will apply to these deeperliving species of seep tubeworms in the GoM as they are phylogenetically closely 
related and have very similar anatomy, including "roots." Our preliminary data analysis from the most recent expedition suggests the deeper species may be as long-lived as the ULS species, although further analyses are required to confirm these estimates and verify other similarities to the ULS species.

The same species of mussel found on the ULS, B. childressi, is also present down to 2200-m depth on the lower slope of the GoM, although the deepestliving populations are genetically isolated from the shallower ones (Cordes et al., 2007b). At depths greater than $1000 \mathrm{~m}$ in the GoM, B. brooksi, a mussel with both methanotrophic and chemoautotrophic symbionts (Fisher et al., 1993), occurs either alone or in mixed beds with $B$. childressi. At depths greater than $2200 \mathrm{~m}$, a third species, B. heckeri, is the dominant mussel (Roberts et al., 2007). B. heckeri was recently reported to harbor four different species of symbionts, two of which use reduced sulfur species as energy sources and two of which use reduced carbon species (methane and perhaps methanol) for energy sources (Duperron et al., 2007), suggesting a high degree of metabolic plasticity for this species. Although these deeper-living species have not yet been studied in the same detail as B. childressi, their apparently similar physiology and anatomy along with our observations to date suggest that their presence on the seafloor is also tied to ongoing active fluid expulsion and the presence of substantial concentrations of reduced chemical species at the sediment-water interface.

The fauna associated with the tubeworms and mussels of the lower slope are generally similar to those of the upper slope at broad taxonomic levels, but are almost entirely different at the species level. The common seep- and vent-associated groups, including the alvinocarid shrimp and galatheid crab, are present at all depths, but differ at the species level. The major change in associated fauna is that the grazer niche occupied on the ULS by the common endemic snails Bathynerita naticoidea and Provanna sculpta is filled by the brittle stars Ophiura acies and Ophienigma spinilimbatum in the deeper sites (Cordes et al., 2007b; Roberts et al., 2007). Interestingly, the seep communities of the lower slope are more similar to those from comparable depths on the Barbados accretionary prism and the Blake Ridge than they are to the upper-slope communities (Cordes et al., 2007b). Furthermore, there is as comparable a degree of phylogenetic similarity in several taxa from the GoM and the west coast of Africa at similar depths as

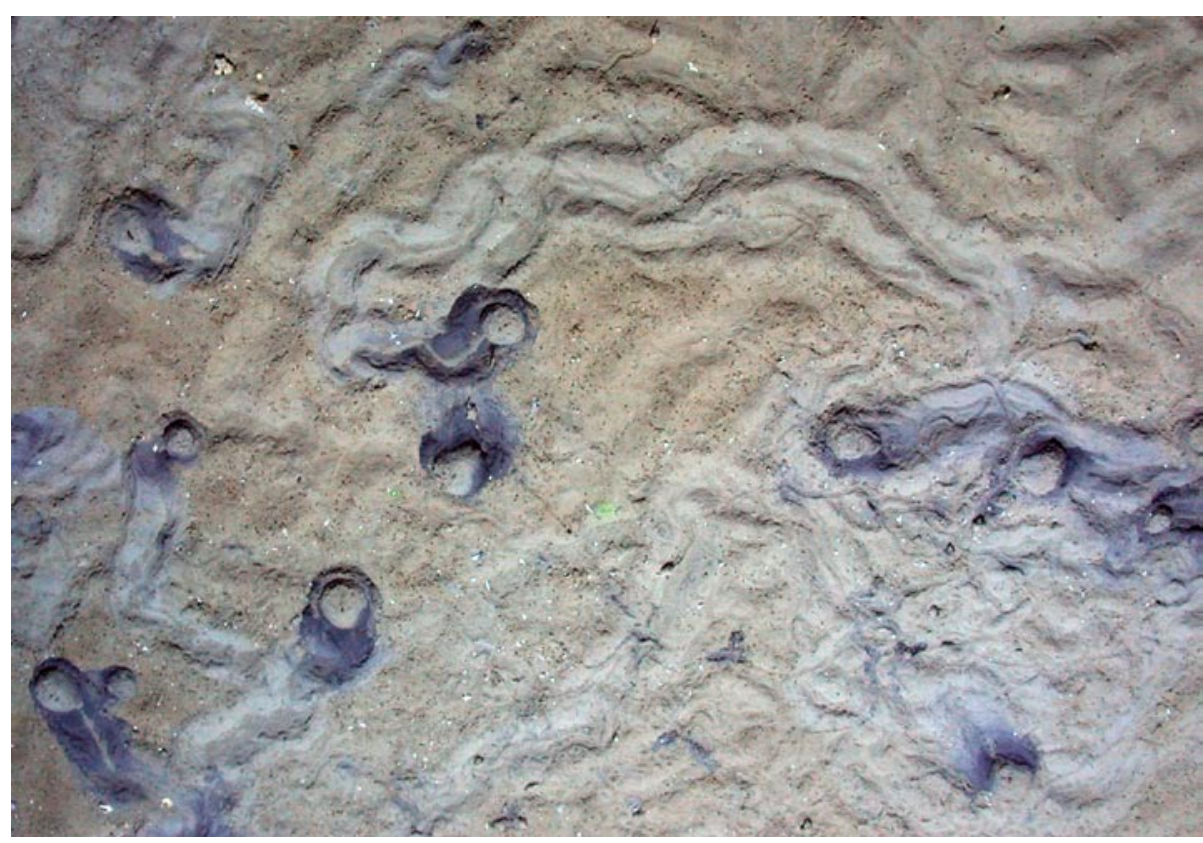

Figure 9. Heart urchins and their trails in reduced sediments in the Atwater Valley lease block 340 at 2200-m depth. The green laser dots are 10-cm apart. Photo courtesy of S. Lessard-Pilon there is among the upper- and lowerslope sites within the GoM.

In addition to the variety of tubeworm and mussel communities found at the deeper sites, several other types of seep communities are present at these depths. Similar to the shallower sites on the ULS, vesicomyid clams were occasionally present in low densities, but no living, highdensity aggregations have yet been found. High-density communities of symbiontcontaining pogonophoran tubeworms were also found at several sites and their study is ongoing. One of the surprising discoveries at several of the deepest sites recently visited (below $2100 \mathrm{~m}$ ) was large aggregations of heart urchins in highly reduced sediments (Figure 9). Our preliminary investigations did not reveal any obvious symbiont-containing tissues, although the trophic biology and physiological ecology of these seep-associated animals are not yet well studied. 


\section{CONCLUSION}

Although the Gulf of Mexico cold seeps are the most thoroughly explored and best studied of any in the world, the discoveries from our most recent explorations clearly emphasize how much remains to be revealed in even relatively well-studied regions of the world's ocean, particularly in the deep sea. There is little doubt that continued direct exploration of the seafloor, guided by increasing understanding of surface-collected data, will efficiently yield discoveries of new geological features, new types of communities, and many new species of animals and microbes. Despite the well-documented and recurring trends in community structure discussed in this review, strong relationships between specific environmental characteristics and the identities and abundances of seep fauna remain elusive. Numerous chemical, physical, and biological characteristics interact and co-vary with the type and successional stages of biogenic structures, and the structure-associated communities interact to varying extents with the surrounding benthos. Shifts in community structure are among the most notable robust trends across a range of depths and community types. These shifts include a lack of macro- and megafauna on nonstructured bacterial mats, endemic primary consumers in productive and toxic small structures, highly diverse and trophically complex communities on large chemically heterogenous structures, and less-diverse, predator-dominated communities in large, nonproductive, chemically benign structures. Further studies are required to determine whether the observed changes in community structure are due primarily to changes in pro- ductivity, toxicity, physical habitat structure, predatory activities, or interactions among all of the above.

\section{ACKNOWLEDGEMENTS}

The authors acknowledge the Minerals Management Service, the NOAA Ocean Exploration Program, the NOAA National Undersea Research Program, and the National Science Foundation, which have all supported our work in the Gulf of Mexico for many years. We also acknowledge Derk Bergquist for inspiring discussions, graphic artist Mary Lee Eggart for illustrations, and Michael Kullman for assistance with the preparation of Figure 3. שי山

\section{REFERENCES}

Bergquist, D.C., F.M. Williams, and C.R. Fisher. 2000. Longevity record for deep-sea invertebrate. Nature 403:499-500.

Bergquist, D.C., I.A. Urcuyo, and C.R. Fisher. 2002. Establishment and persistence of seep vestimentiferan aggregations from the upper Louisiana slope of the Gulf of Mexico. Marine Ecology Progress Series 241:89-98.

Bergquist, D.C., J. Andras T. McNelis, S. Howlett, M.J. van Horn, and C.R. Fisher. 2003. Succession in upper Louisiana slope cold seep vestimentiferan aggregations: The importance of spatial variability. Marine Ecology Progress Series 24:31-44.

Bergquist, D.C., C. Fleckenstein, J. Knisel, B. Begley, I.R. MacDonald, and C.R. Fisher. 2005. Variations in seep mussel bed communities along physical and chemical environmental gradients. Marine Ecology Progress Series 293:89-97.

Brooks, J.M., H.B. Cox, W.R. Bryant, M.C. Kennicutt, R.G. Mann, and T.J. McDonald. 1986. Association of gas hydrates and oil seepage in the Gulf of Mexico. Organic Geochemistry 10:221-234.

Brooks, J.M., M.C. Kennicutt II, C.R. Fisher, S.K. Macko, K. Cole, J.J. Childress, R.R. Bidigare, and R. Vetter. 1987. Deep-Sea hydrocarbon seep communities: Evidence of energy and nutritional carbon sources. Science 238:1,138-1,142.

Brooks, J.M., D.A. Wiesenburg, H. Roberts, R.S. Carney, I.R. MacDonald, C.R. Fisher, N.L. Guinasso, W.W. Sager, S.J. McDonald, R.A. Burke, and others. 1990. Salt, seeps and symbiosis in the Gulf of Mexico. EOS Transactions, American Geophysical Union 71:1,772-1,773.

Cary, S.C., C.R. Fisher, and H. Felbeck. 1988. Mussel growth supported by methane as sole carbon and energy source. Science 240:78-80.

Childress, J.J., C.R. Fisher, J.M. Brooks, M.C. Kennicutt II, R. Bidigare, and A.E. Anderson. 1986. A methanotrophic marine molluscan symbiosis: Mussels fueled by gas. Science 233:1,306-1,308.

Cordes, E.E., M.A. Arthur, K. Shea, and C.R. Fisher. 2005a. Modeling the mutualistic interactions between tubeworms and microbial consortia. Public Library of Science, Biology 3:e77.

Cordes, E.E., D.C. Bergquist, B.L. Predmore, C. Jones, P. Deines, G. Telesnicki, and C.R. Fisher. 2006. Alternate unstable states: Convergent paths of succession in hydrocarbon-seep tubeworm-associated communities. Journal of Experimental Marine Biology and Ecology 339:159-176.

Cordes, E.E., D.C. Bergquist, M.L. Redding, and C.R. Fisher. 2007a. Patterns of growth in cold-seep vestimenferans including Seepiophila jonesi: A second species of long-lived tubeworm. Marine Ecology 28:160-168.

Cordes, E.E., S.L. Carney, S. Hourdez, R. Carney, J.M. Brooks, and C.R. Fisher. 2007b. Cold seeps of the deep Gulf of Mexico: Community structure and biogeographic comparisons to Atlantic and Caribbean seep communities. Deep-Sea Research Part I 54:637-653.

Cordes, E.E., S. Hourdez, B.L. Predmore, M.L. Redding, and C.R. Fisher. 2005b. Succession of hydrocarbon seep communities associated with the long-lived foundation species Lamellibrachia luymesi. Marine Ecology Progress Series 305:17-29.

Cordes, E.E., M. McGinley, E. Podowski, E.L. Becker, S. Lessard-Pilon, S.T. Viada, and C.R. Fisher. In Press. Coral communities of the deep Gulf of Mexico. Marine Ecology Progress Series.

Dattagupta, S., L.L. Miles, M.S. Barnabei, and C.R. Fisher. 2006. The hydrocarbon seep tubeworm Lamellibrachia luymesi primarily eliminates sulfate and hydrogen ions across its roots to conserve energy and ensure sulfide supply. Journal of Experimental Biology 209:3,795-3,805.

De Jong, A. 1968. Stratigraphy of the Sigsbee Scarp from reflection survey. Paper presented at Society of Exploration Geophysicists meeting, Fort Worth, TX. (Abstract on p. 51.)

Diegel, F.A., J.F. Karlo, D.C. Schuster, R.C. Shoup, and P.R. Tauvers. 1995. Cenozoic structural evolution and techono-stratigraphic framework of the northern Gulf coast continental margin. Pp. 109-151 in Salt Tectonics: A Global Perspective. M.P.A. Jackson, D.G. Roberts, and S. Snelson, eds, American Association of Petroleum Geologists Memoir 65.

Duperron, S., M. Sibuet, B.J. MacGregor, M.M. Kuypers, C.R. Fisher, and N. Dublier. 2007. Diversity, relative abundance and metabolic potential of bacterial endosymbionts in three Bathymodiolus mussel species from cold seeps in the Gulf of Mexico. Environmental Microbiology 9:1,423-1,438.

Fisher, C.R., J.J. Childress, and N.K. Sanders. 1988. The role of vestimentiferan hemoglobin in providing an environment suitable for chemoautotro- 
phic sulfide oxidizing endosymbionts. Symbiosis 5:229-246.

Fisher, C.R., J.M. Brooks, J. Vodenichar, J. Zande, J.J. Childress, and R.A. Burke Jr. 1993. The co-occurrence of methanotrophic and chemoautotrophic sulfur-oxidizing bacterial symbionts in a deep-sea mussel. Marine Ecology 14:277-289.

Fisher, C.R., I.R. MacDonald, R. Sassen, C.M. Young, S. Macko, S. Hourdez, R. Carney, S. Joy, and E. McMullin. 2000. Methane ice worms: Hesiocaeca methanicola colonizing fossil fuel reserves. Naturwissenschaften 87(4):184-187.

Freytag, J.K., P. Girguis, D.C. Bergquist, J.P. Andras, J.J. Childress, and C.R. Fisher. 2001. A paradox resolved: Sulfide acquisition by roots of seep tubeworms sustains net chemoautotrophy. Proceedings of the National Academy of Sciences of the United States of America 98:13,408-13,413.

Geyer, R.A., and C.P. Giammona. 1980. Naturally occurring hydrocarbons in the Gulf of Mexico and Caribbean Sea. Pp. 37-106 in Marine Environmental Pollution I, Hydrocarbons. Elsevier Scientific, New York.

Humphries, C.C. Jr. 1978. Salt movement on continental slope, northern Gulf of Mexico. Pp. 68-86 in Framework, Facies and Oil-Trapping Characteristics of the Upper Continental Margin. A.H. Bouma, G.T. Moore, and J.M. Coleman, eds, American Association of Petroleum Geologists Studies in Geology 7.

Joye, S.B., A. Boetius, B.N. Orcutt, J.P. Montoya, J.N. Schulz, M.J. Erickson, and S.K. Lugo. 2004. The anaerobic oxidation of methane and sulfate reduction in sediments from Gulf of Mexico cold seeps. Chemical Geology 205:219-238.

Julian, D., F. Gaill, E. Wood, A.J. Arp, and C.R. Fisher. 1999. Roots as a site of hydrogen sulfide uptake in the hydrocarbon seep vestimentiferan Lamellibrachia sp. Journal of Experimental Biology 202:2,245-2,257.

Kennicutt II, M.C., J.M. Brooks, R.R. Bidigare, R.R. Fay, T.L. Wade, and T.J. McDonald. 1985. Vent-type taxa in a hydrocarbon seep region on the Louisiana slope. Nature 317:351-353.

Kochevar, R.E., J.J. Childress, C.R. Fisher, and E. Minnich. 1992. The methane mussel: Roles of symbiont and host in the metabolic utilization of methane. Marine Biology 112:389-401.

Lee, R.W., E.V. Thuesen, J.J. Childress, and C.R. Fisher. 1992. Ammonium and free amino acid uptake by a deep-sea mussel containing methanotrophic bacterial symbionts. Marine Biology 113:99-106.

MacDonald, I.R., W.W. Sager, and M.B. Peccini. 2003. Association of gas hydrate and chemosynthetic fauna in mounded bathymetry at mid-slope hydrocarbon seeps: Northern Gulf of Mexico. Marine Geology 198:133-158.

MacDonald, I.R., G. Bohrmann, E. Escobar, F. Abegg, P. Blanchon, V. Blinova, W. Brückmann, M. Drews, A. Eisenhauer, X. Han, and others. 2004. Asphalt volcanism and chemosynthetic life, Campeche Knolls, Gulf of Mexico. Science 304:999-1,002.
MacAvoy, S.E., C.R. Fisher, R.S. Carney, and S.A. Macko. 2005. Nutritional associations among fauna at hydrocarbon seep communities in the Gulf of Mexico. Marine Ecology Progress Series 292:51-60.

McBride, B.C. 1998. The evolution of allochthonous salt along a megaregional profile across the northern Gulf of Mexico Basin. American Association of Petroleum Geologists Bulletin 82:1,037-1,055.

McBride, B.C., P. Weimer, and M.G. Rowan. 1998. The effect of allochthonous salt on the petroleum systems of northern Green Canyon and Ewing Bank (offshore Louisiana), northern Gulf of Mexico. American Association of Petroleum Geologists Bulletin 82:1,083-1,112.

Micheli, F., C.H. Peterson, L.S. Mullineaux, C.R. Fisher, S.W. Mills, G. Sancho, G.A. Johnson, and H.S. Lenihan. 2002. Predation structures communities at deep-sea hydrothermal vents. Ecological Monographs 72:365-382.

Nelson, D.C., and C.R. Fisher. 1995. Chemoautotrophic and methanotrophic endosymbiotic bacteria at vents and seeps. Pp. 125-167 in Microbiology of Deep-Sea Hydrothermal Vent Habitats, D.M. Karl, ed., CRC Press, Boca Raton, FL.

Nix, E., C.R. Fisher, K.M. Scott, and J. Vodenichar. 1995. Physiological ecology of a mussel with methanotrophic symbionts at three hydrocarbon seep sites in the Gulf of Mexico. Marine Biology 122:605-617.

Page, H.M., C.R. Fisher, and J.J. Childress. 1990. Role of filter-feeding in the nutritional biology of a deep-sea mussel with methanotrophic symbionts. Marine Biology 104:251-257.

Paull, C.K., B. Hecker, R. Commeau, R.P. FreemanLynde, C. Neumann, W.P. Corso, S. Golubic, J.E. Hook, E. Sikes, and J. Curray. 1984. Biological communities at the Florida escarpment resemble hydrothermal vent taxa. Science 226:965-967.

Peel, F.J., C.J. Travis, and J.R. Hossack. 1995. Genetic structural provinces and salt tectonics of the Cenozoic offshore U.S. Gulf of Mexico: A preliminary analysis. Pp. 153-175 in Salt Tectonics: A Global Perspective, M.P.A. Jackson, D.G. Roberts, and S. Snelson, eds, American Association of Petroleum Geologists Memoir 65.

Roberts, H.H., R. Sassen, R. Carney, and P. Aharon. 1989. Carbonate buildups on the continental slope off central Louisiana. Pp. 655-662 in Proceedings, $21^{\text {st }}$ Offshore Technology Conference, OTC Paper 5953.

Roberts, H.H., and R.C. Carney. 1997. Evidence of episodic fluid, gas, and sediment venting on the northern Gulf of Mexico continental slope. Economic Geology 92:863-879.

Roberts, H.H. 2001. Fluid and gas expulsion on the northern Gulf of Mexico continental slope: Mudprone to mineral-prone responses. Pp. 145-161 in Natural Gas Hydrates: Occurrence, Distribution, and Detection. C. K. Paull and W. P. Dillon, eds, Geophysical Monograph 124, American
Geophysical Union, Washington, DC.

Roberts, H.H., B.A. Hardage, W.W. Shedd, and J. Hunt Jr. 2006. Seafloor reflectivity: An important seismic property for interpreting fluid/gas expulsion geology and the presence of gas hydrate: The Leading Edge 25:620-628.

Roberts, H.H., C.R. Fisher, B. Bernard, J.M. Brooks, M. Bright, R.S. Carney, E.E. Cordes, S. Hourdez, J.L. Hunt Jr., S.B. Joye, and others. 2007. ALVIN Explores the Deep Northern Gulf of Mexico Slope. EOS Transactions, American Geophysical Union 88:341-342.

Rowan, M.G. 1994. A systematic technique for the sequential restoration of salt structures. Tectonophysics 228:331-348.

Rowan, M.G., M.P.A. Jackson, and B.D. Trudgill. 1999. Salt-related fault families and fault welds in the northern Gulf of Mexico. American Association of Petroleum Geologists Bulletin 83:1,454-1,484.

Sassen, R., I.R. MacDonald, A.G. Requejo, N.L. Guinasso Jr, M.C. Kennicutt II, S.T. Sweet, and J.M. Brooks. 1994. Organic geochemistry of sediments from chemosynthetic communities, Gulf of Mexico slope. Geo-Marine Letters. 14:110-119.

Sibuet, M., and K. Olu. 1998. Biogeography, biodiversity and fluid dependence of deep-sea cold-seep communities at active and passive margins. DeepSea Research II 45:517-567.

Sumner, H.S., B.A. Robison, W.K. Dirks, and J.C. Holliday. 1990. Morphology and evolution of salt/minibasin systems: Lower shelf and upper slope, central offshore Louisiana: P. 48 in Geological Society of America Annual Meeting, Programs with Abstracts, Dallas, Texas, Abstract.

Tunnicliffe, V. 1991. The biology of hydrothermal vents: Ecology and evolution. Oceanography and Marine Biology Annual Reviews. 29:319-407.

Vendeville, B.C., and M.P.A. Jackson. 1993. Rates of extension and deposition determine whether growth faults or salt diapirs form. Pp. 268-268 in Proceedings of the Gulf Coast Section Society of Economic Paleontologists and Mineralogists Foundation 14th Annual Research Conference, Houston, Texas, December 5-8, 1993.

Worrall, D.M. and S. Snelson. 1989. Evolution of the northern Gulf of Mexico, with emphasis on Cenozoic growth faulting and the role of salt. Pp. 97-138 in The Geology of North America: An Overview. W. Bally and A.R. Palmer, eds, Geological Society of America, Decade of North American Geology, A, Boulder, CO. 